\title{
Experts' Consensus to Identify Elements of Career Management Competencies in Work-Based Learning (WBL) Program Using Fuzzy Delphi Analysis
}

\author{
https://doi.org/10.3991/ijet.v14i20.11461 \\ Hazlina Marwan $\left({ }^{\bowtie}\right)$, Azita Ali \\ Universiti Tun Hussein Onn Malaysia, Parit Raja, malaysia \\ mhazlina75@gmail.com
}

\begin{abstract}
Purpose of this study: This study aimed to obtain experts' opinion and consensus on the elements of career management competencies that can be developed through the Work-Based Learning (WBL) program in polytechnic.

Methodology: The research was used the Fuzzy Delphi Method (FDM) to obtain the result. An expert questionnaire based on the mapping analysis from the relevant document analysis and expert interviews has been constructed. This questionnaire contains 3 domains with 35 items and was administered to 16 respondents. Respondents of this study are experts who are appointed according to the expertise and experience in the implementation of WBL, particularly in polytechnic.

Main Findings: The result of the analysis found that 31 elements in line with the FDM condition, which is the threshold value (d) surpass 0.2 , group consensus among experts surpassing $75 \%$ and Fuzzy Score (A) exceeds 0.5. It indicates that all the experts had reached a strong consensus. Meanwhile, there are 4 elements were dropped due to did not meet the fuzzy score requirements. All elements of career management competencies were arranged by need and tailored according to experts ' recommendations.

Applications of this study: Our study underlines the importance of actual work experience through Work-Based Learning (WBL) to nurture the existence of career management competencies among polytechnics' students which may highly relevant to their career development. Thus, this study provides useful findings that can be used as material for research particularly in the field of career development learning, experiential learning, and tertiary education.

Novelty/Originality of this study: As a result, this study produces a list of elements of career management competencies that are crucial for the graduate in an appropriate occupational direction. The result also may offer useful guidance to young workers to enter the labor market as a career-ready and competitive worker.
\end{abstract}

Keywords-Work-Based Learning (WBL), Fuzzy Delphi Method (FDM), Career Management Competencies, Career Development, Polytechnic 


\section{Introduction}

Nowadays, the labor market is highly competitive. Graduates from a learning institution are expected in work-ready mode and must be outfitted with characteristics crucial to earn and preserve gratifying employment. Graduates likewise need to develop exceptional competencies other than academic qualifications as it will enable them to coordinate expeditiously in real work situations. Employers too demanding in recruiting new workers to fill vacancies in their organization, and presume young workers generated by higher learning institutions can meet the features they need. However, some graduates seem to be insufficiently ready for entering this present reality of work. In addition, most of the employers are still dissatisfied with the level of graduate's readiness to play a role in the real workplace (1).

The output of graduates in Malaysia shows an upward trend every year. For instance, the output of graduates in 2016 is 238,187 and based on statistics released by the Ministry of Higher Education Malaysia (2018), the output of graduates in 2017 has increased to 255,099 . Unfortunately, due to the limited number of available positions, industries could not offer many jobs for graduate holders and will lead to increasing competition among graduates. In addition, the inequality in supply to the graduate market claim will rise to several matters such as unemployment and employability of graduates (Ismail, Ishak Yusof, \& Sieng Lai Wei, 2011; Yusof, Jamaluddin, \& Lazim, 2013).

Based on literature studies, the quality of graduates is one of the main causes contributing to the joblessness rate in Malaysia. One of the reason is most of the graduates have difficulties in relating what they learn in learning institutions with real work roles. In addition, most young workers from higher learning institutions also have low execution in the workplace and lack of employability skills (Ismail et al., 2011). Research finding from Hanapi and M. Safarin (2014) demonstrate that a large percentage of the young employees graduating from higher learning institutions have problems in terms of employability skills including communication skills problems, are not well-disciplined and lack of leadership skills. Therefore, it is essential that graduates to ace different types of jobs skills in preparing to start their profession.

Graduates should position themselves in relation to future work and be able to effectively manage their career paths on their own. However, most of the graduates do not independently take part in dynamic reasoning about their future career until graduation (6). The report in Graduate Employability Blueprint (2012-2017) shows that the student's preparation for career exploration, especially in terms of attitude development, personality and skills in managing career, still does not meet employers' needs in the job market (7). In addition, most of the graduates have a moderate and low level of work readiness (M. Izwan Mahmud et al., 2016). However, this lack of work readiness can't be entirely ascribed to an absence of graduates' commitment but the role of the higher learning institution to overcome this problem also crucial. It is significant for a higher learning institution to play a key role in ensuring and understanding employer skills requirements, so graduates more prepared and will function effectively in the workplace (McMurray, Dutton, McQuaid, \& Richard, 2016). 
There are a few pieces of evidence show that WBL implementation can become the mechanism for improving career management competencies and career awareness. Thus, it helps graduates to manage their careers effectively and improves their employability. It is consistent with the study by Darche et al. (2009), Jackson and Wilton (2016), and Mari-Hall et al. (2013), which demonstrated that learning opportunities in real workplace environments can contribute significantly to the development of career management competencies as well as the development of graduates' new careers. Bridgstock (2009) acclaims that the career management competencies development in higher learning institution programs needs to start early and should be a compulsory and assessable component of coursework. Hence, this study aimed to obtain an experts opinion and consensus on the elements of career management competencies that can be mastered by students through the WBL program in polytechnic.

\section{$2 \quad$ Literature Review}

\subsection{Work-based learning}

The term of Work-Based Learning (WBL) is widely used in the field of education to illustrate the diversity of workplace learning approaches. In the view of Siregar (2018), WBL stand for a methodology of learning that employs the workplace to gain real work experiences that contribute to learners' career development and lifelong learning. Nikolova et al.,(2014) describing Work-Based Learning as a process by which students acquire new or develop further their existing knowledge, skills, abilities and other features by participating in genuine workplace activities and interactions. According to (Atkinson (2015), the learning process through WBL can develop students' special skills and knowledge in the workplace, as well as enhance understanding of work culture and professionalism.

The concept of WBL implementation combines the theory and practice, knowledge and experience (17). Thus, this concept offers exceptional chances to learn in and through work. Students, the employer, and the learning institution are key stakeholders in work-based learning implementation. Their interests in Work-Based Learning will vary. So, the collaboration between the learning institution on the one hand and industry on the other hand, in WBL implementation can contribute to closing the gap between academia and industry (18). The stronger tripartite relationship which will not only improve learning, but also result in repeat business (Crossan, McTavish, \& Bayley, 2010). WBL program can also provide employers with the opportunity to recruit the most talented young workers, and then give the employer an overview of whether the participants have the necessary features by the organization (10). Indirectly, will reducing the cost of recruiting new employees.

Learning approach using WBL are relevant to realization the mission of vocational education, as students will be able to build their knowledge, skills, and behavior for their career purpose $(16,21)$. WBL also provides an opportunity for the students to use their existing knowledge as the basis for new knowledge, to improve work-related learning skills and at the same time exploit the workplace as a learning resource (20). 
Accordingly, whatever WBL structure is given to students, it should be stressed that what is learned at work can become the basis and valuable knowledge for students to achieve their career goals.

\subsection{Career management competencies}

Career management competencies are characterized as a skill, attributes, attitudes, and knowledge required by individuals to manage their career effectively (Hooley, Watts \& Sultana, 2013). In the view of Bridgstock (2009), career management competencies refer to the ability of an individual to explore the career world proactively and manage career development successfully based on adaptability and lifelong learning. Meanwhile, Akkermans et al., (2013) define career management competencies as a key knowledge, skills, and capabilities for career development where they can be influenced and developed by individuals. In other words, career management competency is considered to be a variety of competencies that provide a more organized way for individuals or groups to collect, analyze, synthesize and compile information, education, and employment, as well as skills, to make decisions and changes (24).

Career management competencies will assist graduates in identifying their existing skills, developing career learning goals, and taking action in improving their career (25). Each student and a graduate have its' own goals, skills, strengths and weaknesses. Therefore, career management competencies can assist them in navigating career paths and exploring increasingly complex and frequently changing job markets from time to time (Mari-Hall, Ulicna \& Duchemin, 2013). In addition, a good element of career management competencies can also help graduates achieve their career goals, increase their workability and success in work (Mason, Williams \& Cranmer, 2009; Sung, Turner \&Kaewchinda, 2013; Despina et al., 2015). Based on some of the definitions discussed above, it can be concluded that career management competencies are the ability of graduates to acquire a wide range of knowledge and skills continuously covering aspects of career planning and development to help graduates manage and determine career direction.

As indicated by Jackson and Wilton (2016), career management competencies are important for long-term career development. Mastering skills in career management will not only contribute to career success, but will also contribute to personal development, aspirations, and well-being of employee (Akkermans et al., 2013). From the point of individual interest, this competency can help make a career choice, can cultivate self-improvement, and feature their potential in their profession.

The process of learning at a higher learning institution is a critical moment for students' career development, and there are various challenges related to current and post-graduate careers (28). Therefore, there is a need to provide students with career management competencies as the basis for starting a career to be able to compete in the current job market. In such manner, higher learning institutions should play a role in providing career management education and awareness in order to have a positive impact on graduate career development and progress, and subsequently produce graduates who are not only skilled but also able to meet job market needs. 


\subsection{Development of career management competencies through the work- based learning program}

The development of career management competencies entails a higher level of the learning process instead of the old-style learning setting (30). Therefore, experience gained on work placement is an effective way to develop the skills and competencies that are highly relevant to the career development of graduates. This opinion consistent with Mari-Hall et al. (2013) which explains that the learning process based on real work experience such as Work-Based Learning (WBL) approach is a good platform to develop career management competencies. Furthermore, the element of career exploration in WBL can expose learners to different principles of work to help them in setting on decisions about upcoming career and jobs according to their interests, values, beliefs, and strengths. (31). Watts (2006) notes that good cooperation between employers and academicians in developing effective WBL implementation will make students more active and positive involvement in the career development process.

Students can foster a variety of competencies during their participation in real work learning activities, and problems in a work context they encounter every day at the workplace. Thus, the learning process from real work experience can contribute to enhancing graduates' understanding of skills and specific roles in the field of work (33). In addition, through WBL programs, learners will have the opportunity to learn and work directly with a mentor or trainer who has a lot of specialized experience in a particular field (10), and offers learners the chance to carry out real production-related assessments and to cooperate with peers and clients (34). This opportunity will indirectly improve the quality of the graduates related to, their attitude, self-efficacy and skills to solve the work problems.

Besides being able to cultivate work skills, exposure to work experience opportunities can similarly help graduates increase they're thoughtful on the field of work and explore their career options $(10,35)$. Students participating in the WBL program also have the occasion to develop an understanding of the culture and expectations of the workplace (11). There are a couple of evidence demonstrates that students can raise their availability to work mostly from the fact of developing soft skills, such as selfefficacy and teamwork skills through WBL programs (36). In acquiring the appropriate level of employment after graduation, students with work placement experience have greater confidence in their own aptitudes and capacities, they likewise have more work understanding to attract upon connection to job roles and organizational requirements (37). However, there may be differences in the level of skills and competencies that students can develop at the workplace, which is reliant to circumstances faced by the students, their level of knowledge acquisition, and the support provided during the WBL program.

\section{Methodology}

In order to identify the elements of career management competencies based on expert consensus, the Fuzzy Delphi method (FDM) was used in this study. FDM is not a new technique, it is a method of measurement performed with modifications based on 
the Delphi method to make it a more effective measurement tool (M. Ridhuan M. Jamil et al., 2017). This enhancement was fashioned due to some traditional Delphi deficiency, for example, low convergence in producing results, lack of significant data from expert views, and lengthy inquiry advancement (39). This method depends on gathering conclusion of the competent experts which ensures the validity of the data gathered (40), where the insignificant criteria can be recognized and disposed of from further consideration.

Fuzzy Delphi method (FDM) involves the utilization of Fuzzy set theory that has been integrated into the traditional Delphi method, where the Likert scale chosen by the expert will be converted to Fuzzy scale by using fuzzy numbering which consists of binary term naming $(0,1)$. This Fuzzy number integration will upshoot in 3 values that are the minimum value, the most reasonable value and the maximum value chosen by the expert.

The quality of the FDM resides in its capacity to consistently generate verification outcomes and verify the elements through expert opinion and consensus (41). FDM additionally is a compelling strategy that does not require numerous rounds of validation (M. Ridhuan M. Jamil et al., 2015) thus, it's considered as an excellent method of saving the time in term of convergence of experts' options and cost of handling the questionnaires. More importantly, FDM can provide a chance for specialists to express their views without misinterpreting the main view of an expert, thus truly reporting their responses (40). Therefore, FDM is widely utilized in various applications, such as engineering, humanities, business and management, and physical science (41).

\subsection{Respondents}

Respondents consisted of sixteen experts those involved in WBL program at Polytechnics Malaysia. All the experts were selected using a purposive sampling method to fulfill the requirements necessary in responding to the research question. This method was chosen because the researchers wanted to get an expert opinion and consensus in identifying the elements of competence to be assessed. Based on the opinion of Adler and Ziglio (1996) it is sufficient to involve ten to fifteen experts if there is a high level of uniformity among the experts.

The selection of experts is very important and it should be consistent with the context of the study conducted. Therefore, the experts chosen are the academician and industrial experts in the fields related to our research. There are from different backgrounds in polytechnics application of WBL were taken into consideration to maximize the effectiveness of the study.

The selected expert should have at least 5 years of working experience in their field in terms of expertise. The rationale for this choice of specialists is to obtain a broad variety of distinct experiences and views on career management competencies depending on their corresponding field of knowledge in implementing WBL, particularly in polytechnics. According to Berliner (2004), it is possible to classify as specialists those with expertise in a field continuously for more than five years. While, in the education field, Akbari and Yazdanmehr (2014) explain that individuals with more than five years of experience in their specific field can refer to it like an expert. 


\subsection{Procedure for collecting data}

There are two phases of procedure that the researcher uses to explore and validate the elements of career management competencies as shown in Table 1.

Table 1. Data Collection of Fuzzy Delphi Method

\begin{tabular}{|l|l|l|}
\hline \multicolumn{1}{|c|}{ Phases } & \multicolumn{1}{|c|}{ Instrument Design } & \multicolumn{1}{c|}{ Total Expert } \\
\hline Establishment of Expert questionnaire & $\begin{array}{l}\text { i. Document analysis } \\
\text { ii. Structured Interviewed }\end{array}$ & 5 experts \\
\hline Obtain consensus & Expert questionnaire & 16 experts \\
\hline
\end{tabular}

In the first phase, the collection of data included document analysis, such as reports, blueprint, and related research on career management competencies and WBL implementation. This study also conducted a semi-structured interview with five experts in WBL implementation in polytechnic. The interview protocol has been ready in advance. Based on the mapping analysis from relevant document analysis and interviews with experts, the researchers gathered the constructs and elements of competencies and were used for developing the expert questionnaire.

The second phase, the expert questionnaire was intended to assemble experts opinion on the elements of career management competencies that students can master through work-based learning (WBL). The expert questionnaire consists of 3 main constructs with 35 elements of competencies. Seven linguistic terms which are employed in this questionnaire are as follows: very strongly agree, strongly agree, agreed, not sure, disagree, strongly disagree, and very strongly disagree. The number of levels of the linguistic agreement must be in odd numbers and the higher the fuzzy scale, the more precise the information acquired $(46,47)$.

Then, experts required demonstrating the degree of their concurrence with the statements given. All the more critically, the experts were mentioned to give recommendations to extra measures and reasons to legitimize their ideas. The expert questionnaire was administered to 16 selected experts in WBL.

\subsection{Data analysis}

All linguistic variables from the experts' response in the expert questionnaire were transformed into triangular Fuzzy numbering as illustrated in Table 2. Then, the experts' responses were analyzed based on the three conditions contained in the triangular fuzzy number and defuzzification process.

Table 2. Linguistic variables and Fuzzy Scale

\begin{tabular}{|l|l|l|l|l|l|l|l|}
\hline $\begin{array}{c}\text { Likert } \\
\text { Scale }\end{array}$ & $\mathbf{1}$ & $\mathbf{2}$ & $\mathbf{3}$ & $\mathbf{4}$ & $\mathbf{5}$ & $\mathbf{6}$ & $\mathbf{7}$ \\
\hline $\begin{array}{l}\text { Linguistic } \\
\text { Variable }\end{array}$ & $\begin{array}{l}\text { Very strong- } \\
\text { ly disagree }\end{array}$ & $\begin{array}{l}\text { Strongly } \\
\text { disagree }\end{array}$ & Disagree & Not sure & Agreed & $\begin{array}{l}\text { Strongly } \\
\text { agreed }\end{array}$ & $\begin{array}{l}\text { Very strong- } \\
\text { ly agree }\end{array}$ \\
\hline Fuzzy Scale & $0.0,0.0,0.1$ & $0.0,0.1,0.3$ & $0.1,0.3,0.5$ & $0.3,0.5,0.7$ & $0.5,0.7,0.9$ & $0.7,0.9,1.0$ & $0.9,1.0,1.0$ \\
\hline
\end{tabular}

Source:(39,47) 
The first requirement to be pursued in FDM analysis is a threshold value (d). The value of the threshold (d) will determine the level of expert consensus for each item. The threshold value $(\mathrm{d})$ of each item ought not to surpass $0.2(38,39)$ that implies that all expert agrees with that statement of that particular item. The value $\left(\mathrm{n}_{1}, \mathrm{n}_{2}, \mathrm{n}_{3}\right)$ representing the value of Fuzzy element and the value $\left(\mathrm{m}_{1}, \mathrm{~m}_{2}, \mathrm{~m}_{3}\right)$ representing average Fuzzy value for each item is required in determining the threshold value. Therefore, to obtain the threshold value, the distance between two Fuzzy numbers, $\widetilde{m}$ and $\tilde{n}$ is computed by:

$$
d(\tilde{m}, \tilde{n})=\sqrt{\frac{1}{3}\left[\left(m_{1}-n_{1}\right)^{2}+\left(m_{2}-n_{2}\right)^{2}+\left(m_{3}-n_{3}\right)^{2}\right]}
$$

The second condition that needs to be observed in FDM analysis is group consensus among the experts must be equal to or greater than $75.0 \%(38,39)$. Afterward, the third condition in FDM analysis can be carried out through the defuzzification process, where the estimated fuzzy score (A) will be determined. According to Tang and $\mathrm{Wu}$ (2010), an expert consensus has been achieved when the value of fuzzy score (A) equal to or greater than the median value ( $\alpha$ - cut) by 0.5 . Alternatively, the priority for an element (ranking order) based on experts' views can be determined according to Fuzzy score (A) value. This fuzzy score (A) value is computed by:

$$
A=\frac{1}{3}(m 1+m 2+m 3)
$$

\section{$4 \quad$ Results and Findings}

In all, 16 expert questionnaires were successfully returned. A total of 35 elements of career management competencies representing the learning and work exploration competencies (11 elements), personal management competencies (12 elements), and career development competencies (12 elements) were analyzed using Fuzzy Delphi Method (FDM). The principle of FDM analysis is used to find whether the expert consensus can be achieved referring to the following conditions:

- Threshold value (d) of each item should surpass 0.2

- An agreement of experts surpassing $75 \%$

- The value of Fuzzy score (A) surpasses 0.5

Summary of FDM analysis by showing the calculated threshold values, percentages of experts' agreement, Fuzzy score (A) value and ranking elements of career management competencies are illustrated in the following table of analysis.

Table 3. Summary of Fuzzy Delphi (FDM) Analysis for Personal Management Competencies

\begin{tabular}{|c|c|c|c|c|c|c|}
\hline Construct & Elements of Competence & $\begin{array}{c}\text { Threshold } \\
\text { Value }, \mathrm{d} \\
(\boldsymbol{d}<\mathbf{0 . 2})\end{array}$ & $\begin{array}{c}\text { Percent of } \\
\text { expert } \\
\text { Agreement }\end{array}$ & $\begin{array}{c}\text { Fuzzy } \\
\text { Score } \\
(A \geq 0.5)\end{array}$ & $\begin{array}{c}\text { Expert } \\
\text { consensus }\end{array}$ & Ranking \\
\hline
\end{tabular}




\begin{tabular}{|l|l|c|c|c|l|c|}
\hline & & & $\mathbf{( \geq 7 5 \% )}$ & & & \\
\hline \multirow{5}{*}{} & Effective communication skills & 0.090 & $93.8 \%$ & $91.9 \%$ & agreed & 1 \\
\cline { 2 - 7 } & Improving self confidence & 0.092 & $93.8 \%$ & $91.3 \%$ & agreed & 2 \\
\cline { 2 - 7 } & $\begin{array}{l}\text { Knowing how to adapt to all the } \\
\text { changes }\end{array}$ & 0.110 & $87.5 \%$ & $90.8 \%$ & agreed & 3 \\
\cline { 2 - 7 } & Good in time management & 0.110 & $87.5 \%$ & $90.2 \%$ & agreed & 4 \\
\cline { 2 - 7 } $\begin{array}{l}\text { Personal } \\
\text { Management }\end{array}$ & $\begin{array}{l}\text { Positive self-image } \\
\text { Interact positively and effective- } \\
\text { ly with others }\end{array}$ & 0.097 & $87.5 \%$ & $88.3 \%$ & agreed & 6 \\
\cline { 2 - 7 } & Talented in the field of work & 0.119 & $87.5 \%$ & $87.1 \%$ & agreed & 7 \\
\cline { 2 - 7 } & Maintaining good relationship & 0.079 & $87.5 \%$ & $87.1 \%$ & agreed & 8 \\
\cline { 2 - 7 } & Personal and work balance & 0.105 & $81.3 \%$ & $86.7 \%$ & agreed & 9 \\
\cline { 2 - 7 } & Creative and innovative & 0.097 & $81.3 \%$ & $86.0 \%$ & agreed & 10 \\
\cline { 2 - 7 } & $\begin{array}{l}\text { Knowing the strengths and } \\
\text { weaknesses }\end{array}$ & 0.131 & $81.3 \%$ & $85.4 \%$ & agreed & 11 \\
\cline { 2 - 7 } & Change and grow throughout life & 0.176 & $87.5 \%$ & $83.1 \%$ & agreed & 12 \\
\hline
\end{tabular}

Table 3 above showed that each element in the personal management competencies achieved a threshold value $(\mathrm{d}) \leq 0.2$, it indicates that a high consensus was reached by the experts. Similarly, the percentage of experts' agreement for all elements is greater than $75 \%$ and all the values of fuzzy scores (A) exceed 0.5 . This finding shows that the level of experts' consensus for all accepted elements in personal management competence was considered high. All the elements are arranged according to priority based on the values of the fuzzy score $(\mathrm{A})$.

Table 4. Summary of Fuzzy Delphi (FDM) Analysis for Learning and Work Exploration Competencies

\begin{tabular}{|c|c|c|c|c|c|c|}
\hline Construct & Elements of Competence & $\begin{array}{c}\text { Threshold } \\
\text { Value, } \\
(d<0.2)\end{array}$ & $\begin{array}{c}\text { Percent of } \\
\text { expert } \\
\text { Agreement } \\
(\geq 75 \%)\end{array}$ & $\begin{array}{c}\text { Fuzzy } \\
\text { Score } \\
(A \geq 0.5)\end{array}$ & $\begin{array}{c}\text { Expert } \\
\text { consensus }\end{array}$ & Ranking \\
\hline \multirow{11}{*}{$\begin{array}{l}\text { Learning and } \\
\text { Work Explo- } \\
\text { ration }\end{array}$} & $\begin{array}{l}\text { Mastering knowledge in a spe- } \\
\text { cialized field }\end{array}$ & 0.09 & $93.8 \%$ & 0.919 & agreed & 1 \\
\hline & $\begin{array}{l}\text { Apply skills and knowledge in } \\
\text { work roles. }\end{array}$ & 0.089 & $93.8 \%$ & 0.9 & agreed & 2 \\
\hline & Build work networking & 0.084 & $93.8 \%$ & 0.894 & agreed & 3 \\
\hline & $\begin{array}{l}\text { Understand the importance of } \\
\text { education and training in career }\end{array}$ & 0.124 & $81.3 \%$ & 0.885 & agreed & 4 \\
\hline & $\begin{array}{l}\text { Explore the development of } \\
\text { work fields }\end{array}$ & 0.149 & $75.0 \%$ & 0.865 & agreed & 5 \\
\hline & $\begin{array}{l}\text { Identify potentials in the labour } \\
\text { market }\end{array}$ & 0.165 & $75.0 \%$ & 0.863 & agreed & 6 \\
\hline & Relate learning to career goals & 0.137 & $81.3 \%$ & 0.86 & agreed & 7 \\
\hline & Explore career information & 0.131 & $81.3 \%$ & 0.854 & agreed & 8 \\
\hline & $\begin{array}{l}\text { Understand the working condi- } \\
\text { tions of their various roles. }\end{array}$ & 0.158 & $68.8 \%$ & 0.844 & dropped & 9 \\
\hline & $\begin{array}{l}\text { Use career information effective- } \\
\text { ly }\end{array}$ & 0.17 & $68.8 \%$ & 0.84 & dropped & 10 \\
\hline & $\begin{array}{l}\text { Maintain a balanced life and } \\
\text { work roles }\end{array}$ & 0.178 & $68.8 \%$ & 0.808 & dropped & 11 \\
\hline
\end{tabular}


Summary of analysis for learning and work exploration competencies as presented in Table 4, shows that all elements have the threshold value (d) $\leq 0.2$ and the values of fuzzy scores (A) exceed 0.5. However, the percentage of experts' agreement for three elements (use career information effectively, understand the working conditions of their various roles, and maintain a balanced life and work roles) less than $75 \%$ and were dropped because did not pass the second condition. Overall, 8 out of 11 elements were accepted due to having reached a strong expert consensus. All the elements in learning and work exploration competencies are arranged according to priority (ranking order) based on experts' opinions through the values of the fuzzy score (A).

Table 5. Summary of Fuzzy Delphi (FDM) Analysis for Career Building Competencies

\begin{tabular}{|c|c|c|c|c|c|c|}
\hline Construct & Elements of Competence & $\begin{array}{c}\text { Threshold } \\
\text { Value, } \mathrm{d} \\
(d<0.2)\end{array}$ & $\begin{array}{c}\text { Percent of } \\
\text { expert } \\
\text { Agreement } \\
(\geq 75 \%)\end{array}$ & $\begin{array}{c}\text { Fuzzy } \\
\text { Score } \\
(A \geq 0.5)\end{array}$ & $\begin{array}{c}\text { Expert } \\
\text { consensus }\end{array}$ & Ranking \\
\hline \multirow{12}{*}{$\begin{array}{l}\text { Career Build- } \\
\text { ing }\end{array}$} & Teamwork ability & 0.090 & $93.8 \%$ & $91.9 \%$ & agreed & 1 \\
\hline & Developing work-search skills & 0.089 & $93.8 \%$ & $90.0 \%$ & agreed & 2 \\
\hline & Career planning & 0.141 & $75.0 \%$ & $87.5 \%$ & agreed & 3 \\
\hline & $\begin{array}{l}\text { Ability to present oneself effec- } \\
\text { tively in job recruitment pro- } \\
\text { cesses }\end{array}$ & 0.112 & $87.5 \%$ & $86.5 \%$ & agreed & 4 \\
\hline & Problem solving skills & 0.112 & $87.5 \%$ & $86.5 \%$ & agreed & 4 \\
\hline & Ability to present & 0.129 & $75.0 \%$ & $86.3 \%$ & agreed & 6 \\
\hline & Career goal setting & 0.123 & $75.0 \%$ & $85.6 \%$ & agreed & 7 \\
\hline & Improve decision making skills & 0.155 & $75.0 \%$ & $85.0 \%$ & agreed & 8 \\
\hline & $\begin{array}{l}\text { Explore the knowledge and skills } \\
\text { required effectively in the work- } \\
\text { place }\end{array}$ & 0.160 & $81.3 \%$ & $84.2 \%$ & agreed & 9 \\
\hline & Master managing skills & 0.143 & $75.0 \%$ & $83.8 \%$ & agreed & 10 \\
\hline & Enhance report writing skills & 0.176 & $87.5 \%$ & $83.1 \%$ & agreed & 11 \\
\hline & Master good English proficiency & 0.208 & $43.8 \%$ & $82.5 \%$ & dropped & 12 \\
\hline
\end{tabular}

Findings analysis for career-building competencies using FDM (Table 5) showed the values of fuzzy scores (A) for all elements exceed 0.5. However, the element of master good English proficiency was dropped due to the threshold value (d) exceed 0.2 and the percentages of experts' agreement below than $75 \%$. So, 11 out of 12 elements in career building competencies received a high consensus from all the experts. All elements of competencies are arranged according to priority based on experts' opinions.

Overall, based on the finding of the Fuzzy Delphi analysis, the experts believed that work experience acquired on placement using WBL approach can expose students to a multitude of career management competencies that can assist in student career growth. This is in accordance with M. Kuijpers, Meijers, and Gundy (2011) which clarifies learning environments that stimulate real work experiences contributes to the utilization of career management competencies. It also tends to have a positive impact on graduates attitude and commitment headed for acquiring graduate employment. 


\section{Conclusion}

This study utilized the board of expert and Fuzzy Delphi analysis to determine the elements of career management competencies from the standpoints of academia and the industry experts. The findings show the learning process that applies a WorkBased Learning (WBL) approach which is exposing students to a real work environment is an effective way to assist them develops the different elements of career management competencies required to improve career prospect. These elements of competencies are capable of moving students as needed by employers into flexible and versatile employees. In line with findings of this study, numerous current research has revealed that emphasis on developing elements of career management competencies will allow graduates to compete for jobs that are adequate with their abilities and competent. Moreover, the outcomes of this study may be used to plan a more effective and rewarding career education program for WBL students. In future research, it is recommended to extend this study by gathering more data, modifying or adding more elements of competencies and applying this approach to other programs.

\section{References}

[1] Boden R, Nedeva M. Employing discourse: Universities and graduate "employability." J Educ Policy. 2010;25(1):37-54. https://doi.org/10.1080/02680930903349489

[2] Ministry of Higher Education Malaysia. Statistik Pendidikan Tinggi 2017. Kuala Lumpur, Malaysia; 2018.

[3] Ismail R, Ishak Yusof, Sieng Lai wei. Employers' perceptions on graduates in Malaysian services sector. Int Bus Manag. 2011;5(3):184-93.

[4] Yusof N, Jamaluddin Z, Lazim NM. Persepsi Pelajar Prasiswazah Terhadap Kebolehpasaran Graduan dan Persaingan dalam Pasaran Pekerjaan. J Pers Pelajar. 2013;16:77-92.

[5] Hanapi Z, M. Safarin Nordin. Unemployment Among Malaysia Graduates: Graduates' attributes, Lecturers' Competency And Quality Of Education. Int Conf Educ Educ Psychol 2013 (ICEEPSY 2013). 2014;112:1056-63. https://doi.org/10.1016/j.sbspro.2014.01.1269

[6] Perrone L, Vickers MH. Life after graduation as a "very uncomfortable world": An Australian case study. Educ Train. 2003;45(2):69-78. https://doi.org/10.1108/0040091031 $\underline{0464044}$

[7] Ministry of Higher Education Malaysia. The National Graduate Employability Blueprint (2012-2017). Putrajaya, MALAYSIA; 2012.

[8] M. Izwan Mahmud, Sidek M. Noah, Jamaludin Ahmad, W. Marzuki W. Ahmad. Modul Kesediaan Kerjaya Berdasarkan Teori Cognitive Information Processing (CIP). J Kurikulum Pengajaran Asia Pasifik. 2016;4(3):59-75.

[9] McMurray S, Dutton M, McQuaid R, Richard A. Employer demands from business graduates. Educ + Train. 2016;58(1):112-32. https://doi.org/10.1108/et-02-2014-0017

[10] Mari-Hall A, Ulicna D, Duchemin C. Work Based Learning: Benefits and Obstacles - A Literature Review For Policy Makers And Social Partners In ETF Partner Countries. European Training Foundation. 2013.

[11] Darche S, Nayar N, Bracco KR. Work-Based Learning in California: Opportunities and Models for Expansion. Los Angeles; 2009. 
[12] Jackson D, Wilton N. Developing career management competencies among undergraduates and the role of work-integrated learning. Teach High Educ. 2016;21(3):266-86. https://doi.org/10.1080/13562517.2015.1136281

[13] Bridgstock R. The graduate attributes we've overlooked: enhancing graduate employability through career management skills. High Educ Res Dev. 2009; 28(1):31-44. https://doi.org/10.1080/07294360802444347

[14] Siregar S. A Study of Work Based Learning For Construction Building Workers. J Phys Conf Ser. 2018;970(1):1-6.

[15] Nikolova I, Van Ruysseveldt J, De Witte H, Syroit J. Work-based learning: Development and validation of a scale measuring the learning potential of the workplace (LPW). J Vocat Behav. 2014;84(1):1-10. https://doi.org/10.1037/t28894-000

[16] Atkinson G. Work-based learning and work-integrated learning: fostering engagement with employers Work-based learning and work-integrated learning: fostering engagement with employers. National Centre for Vocational Education Research. Adelaide Australia; 2015. https://doi.org/10.1108/heswbl.2011.50501baa.001

[17] Aini W, Kustono D, Dardiri A, Kamdi W. Work-based learning for enhancing the capacity of engagement: Lesson from stakeholders perspective literature. In: Proceedings of the International Mechanical Engineering and Engineering Education Conferences (IMEEEC 2016). Indonesia: AIP Publishing; 2016. p. 51-8. https://doi.org/10.1063/1.4965786

[18] Algers A, Lindström B, Svensson L. Work-based learning through negotiated projects exploring learning at the boundary. High Educ Ski Work Learn. 2012;6(1):2-19. https:// doi.org/10.1108/heswbl-01-2015-0003

[19] Crossan M, McTavish A-M, Bayley V. The reality of employer engagement in work-based learning. ALT J. 2010;10:33-6.

[20] Basit TN, Eardley A, Borup R, Shah H, Slack K, Hughes A. Higher education institutions and work-based learning in the UK: employer engagement within a tripartite relationship. High Educ. 2015;70(6):1003-15. https://doi.org/10.1007/s10734-015-9877-7

[21] Komariah K. The Role of Work-Based Learning in Building Employability Skills of Vocational Education Students. In: Proceedings of the 3Rd Upi International Conference on Technical and Vocational Education and Training. 2015. p. 110-3. https://doi.org/10.29 91/ictvet-14.2015.25

[22] Hooley T, Watts AG, Sultana RG. British Journal of Guidance \& The 'Blueprint' framework for career management skills: a critical exploration. $\mathrm{Br} \mathrm{J}$ Guid Counc. 2013;41(2):117-31. https://doi.org/10.1080/03069885.2012.713908

[23] Akkermans J, Schaufeli WB, Brenninkmeijer V, Blonk RWB. The role of career competencies in the Job Demands - Resources model. J Vocat Behav. 2013;83(3):356-66. https://doi.org/10.1016/j.jvb.2013.06.011

[24] Sultana RG. Learning career management skills in Europe: A critical review. J Educ Work. 2012;25(2):225-48.

[25] Neary S, Dodd V, Hooley T. Understanding career management skills: Findings From the First Phase of the CMS Leader Project. 2016.

[26] Sung Y, Turner SL, Kaewchinda M. Career Development Skills, Outcomes, and Hope Among College Students. J Career Dev. 2013;00(0):1-19. https://doi.org/10.1177/0894845 $\underline{311431939}$

[27] Mason G, Williams G, Cranmer S. Employability skills initiatives in higher education: What effects do they have on graduate labour market outcomes? Educ Econ. 2009;17(1):130. https://doi.org/10.1080/09645290802028315

[28] Despina S-D, Argyropoulou K, Drosos N, Kaliris A, Mikedaki K. Exploring Career Management Skills in Higher Education: Perceived Self-efficacy in Career, Career Adaptability 
and Career Resilience in Greek University Students. Int $\mathrm{J}$ Learn Teach Educ Res. 2015;14(2):36-52. https://doi.org/10.5539/ijps.v10n3p95

[29] Akkermans J, Brenninkmeijer V, Huibers M, Blonk RWB. Competencies for the Contemporary Career: Development and Preliminary Validation of the Career Competencies Questionnaire. J Career Dev. 2012;40(3):245-67. https://doi.org/10.1037/t26080-000

[30] Kuijpers M, Meijers F. Learning for now or later ? Career competencies among students in higher vocational education in the Netherlands. Stud High Educ. 2012;37(4):449-67. https://doi.org/10.1080/03075079.2010.523144

[31] Amadi UPN. Appraising Work-Based Learning Experiences of Technical and Vocational (Teacher) Educationand Training (TVTET) Programmes In Nigeria. Mediterr J Soc Sci. 2013;4(5):107. https://doi.org/10.5901/mjss.2013.v4n5p137

[32] Watts AG. Career development learning and employability. The Higher Education Academy. United Kingdom; 2006.

[33] Jackson D. Employability skill development in work-integrated learning : Barriers and best practice. Stud High Educ. 2015;40(2):350-67.

[34] Luecking R, Gramlich M. Quality Work-Based Learning and Postschool Employment Success. Natl Cent Second Educ Transition,Issue Br. 2003;2(2).

[35] Cedefop. Guidance supporting Europe's aspiring entrepreneurs: Policy and practice to harness future potential. Greece; 2011.

[36] Smith C, Worsfold K. WIL curriculum design and student learning : a structural model of their effects on student satisfaction. Stud High Educ. 2014;39(6):1070-84. https://doi.org/ $\underline{10.1080 / 03075079.2013 .777407}$

[37] Raybould J, Sheedy V. Are graduates equipped with the right skills in the employability stakes? Ind Commer Train. 2005;37(5):259-63. https://doi.org/10.1108/001978505106096 $\underline{94}$

[38] Mohd Ridhuan Mohd Jamil, Saedah Siraj, Zaharah Hussin, Nurulrabihah Mat Noh, Ahmad Ariffin Sapar. Pengenalan Asas Kaedah Fuzzy Delphi Dalam Penyelidikan Rekabentuk dan Pembangunan. Mohd Ridhuan Mohd Jamil, editor. Kuala Lumpur, Malaysia: Minda Intelek Agency; 2017. https://doi.org/10.1080/1059924x.2019.1666763

[39] Chang P, Hsu C, Chang P. Fuzzy Delphi method for evaluating hydrogen production technologies. Int J Hydrogen Energy. 2011;36(21):14172-9. https://doi.org/10.1016/j.ijhy dene.2011.05.045

[40] Glumac B, Han Q, Smeets J, Schaefer W. Brownfield redevelopment features: Applying Fuzzy Delphi. J Eur Real Estate Res. 2011;4(2):145-59. https://doi.org/10.1108/17539261 111157316

[41] Sensuse DI, Purwandari B, Rahayu P. Defining e-Portofolio Factor for Competency Certification using Fuzzy Delphi Method. Turkish Online J Educ Technol. 2018;17(2):25-33.

[42] M. Ridhuan M. Jamil, Siraj S, Hussin Z, Noh NM, Ahmad Arifin Sapar. Aplikasi Teknik Fuzzy Delphi Terhadap Keperluan Elemen Keusahawanan Bagi Pensyarah Kejuruteraan Politeknik Malaysia. Int J Bus Technopreneursh. 2015;5(1):135-50.

[43] Adler M, Ziglio E. Gazing into the oracle: The Delphi method and its application to social policy and public health. Adler M, Ziglio E, editors. London: Jessica Kingsley Publishers; 1996.

[44] Berliner DC. Describing the Behavior and Documenting the Accomplishments of Expert Teachers. Bull Sci Technol Soc. 2004;24(3):200-12.

[45] Akbari R, Yazdanmehr E. A Critical Analysis of the Selection Criteria of Expert Teachers in ELT. Theory Pract Lang Stud. 2014;4(8):1653-8. https://doi.org/10.4304/tpls.4.8.1653$\underline{1658}$ 
[46] Kamarulzaman N, Jomhari N, Mohd Raus N, M. Yusof MZ. Applying the Fuzzy Delphi Method to Analyze the user Requirement for user Centred Design Process in Order to Create Learning Applications. Indian J Sci Technol. 2015;8(32). https://doi.org/10.17485/ ijst/2015/v8i32/92146

[47] Ramlie H, Hussin Z, Siraj S, M. Noh NR, M. Ridhuan M. Jamil, Ahmad Arifin Sapar. Aplikasi Teknik Fuzzy Delphi Terhadap Keperluan Aspek ' Riadhah Ruhiyyah ' Untuk Profesionalisme Perguruan Pendidikan Islam. Online J Islam Educ. 2014;2(2):53-72.

[48] Tang CW, Wu CT. Obtaining a picture of undergraduate education quality: A voice from inside the university. High Educ. 2010;60(3):269-86. https://doi.org/10.1007/s10734-009$\underline{9299-5}$

[49] Kuijpers M, Meijers F, Gundy C. The relationship between learning environment and career competencies of students in vocational education. J Vocat Behav. 2011;78(1):21-30. https://doi.org/10.1016/j.jvb.2010.05.005

\section{$7 \quad$ Authors}

Hazlina Marwan is a Ph.D. Students at the Faculty of Technical \& vocational Education in the University Tun Hussei Onn, Malaysia

Azita Ali work for Universiti Tun Hussein Onn Malaysia as a lecturer at the Faculty of Technical \& vocational Education department.

Article submitted 2019-07-13. Resubmitted 2019-08-16. Final acceptance 2019-08-17. Final version published as submitted by the authors. 